\title{
Evaluation of Cretaceous Hinterland Weathering and Climate in the Sichuan Basin, SW China
}

\author{
Tenichi Cho ${ }^{1 *}$, Hideaki Mantani' ${ }^{1}$, Tohru Ohta1,2, Gang Li $^{3}$ \\ ${ }^{1}$ Graduate School of Creative Science and Engineering, Waseda University, Tokyo, Japan \\ ${ }^{2}$ Faculty of Education and Integrated Arts and Sciences, Waseda University, Tokyo, Japan \\ ${ }^{3}$ State Key Laboratory of Palaeobiology and Stratgraphy, Center for Excellence in Life and Environment, Nanjing Institute \\ of Geology and Palaeontology, Chinese Academy of Science, Nanjing, China \\ Email: *tianct@fuji.waseda.jp
}

How to cite this paper: Cho, T., Mantani, H., Ohta, T. and Li, G. (2019) Evaluation of Cretaceous Hinterland Weathering and Climate in the Sichuan Basin, SW China. Open Journal of Geology, 9, 696-699. https://doi.org/10.4236/ojg.2019.910078

Received: August 17, 2019

Accepted: September 22, 2019

Published: September 25, 2019

Copyright $\odot 2019$ by author(s) and Scientific Research Publishing Inc. This work is licensed under the Creative Commons Attribution International License (CC BY 4.0).

http://creativecommons.org/licenses/by/4.0/ (c) (i) Open Access

\begin{abstract}
Cretaceous is characterized by high atmospheric $\mathrm{CO}_{2}$ concentration and a resultantly high temperature. Thus, the Earth system, which operated during the greenhouse condition, can be deduced by the investigation of the paleoclimate during the Cretaceous. However, information of paleoclimate from continental inland-basins is scarce compared to that from continental margin marine-basins. In this research, the changes of weathering condition through the whole Cretaceous Period were reconstructed by analyzing the whole-rock chemical composition and clay mineral composition of mudstone samples collected in the Sichuan Basin, SW China. The reconstructed paleoweathering intensity positively correlates with paleotemperature estimate, indicating that Cenomanian-Turonian stages were climatic optimum in the Sichuan Basin as well. Furthermore, the result suggests a Cenomanian-Turonian extremely high amplitude humidity fluctuation.
\end{abstract}

\section{Keywords}

Cretaceous, Continental Weathering, Fluvial Deposits, Desert Deposits, XRF, XRD, W Index

\section{Introduction}

Reconstruction of the Cretaceous paleoclimate is important for the understanding of the Earth operating system during the greenhouse conditions. However, paleoclimatic information from continental inland-basins is scarce compared to 
that from continental margin marine-basins. This situation is also true in the Asian continent; Cretaceous ecosystem and paleoclimate data are accumulating in the Pacific side, while those of the Asian continental side are lacking [1]. Paleoclimate conditions in Asian inland basins are considered to be equally important in order to elucidate the land-ocean climate operating system during the Cretaceous.

In this regard, we investigated the geochemistry and clay mineralogy of the Cretaceous mudstones from the Sichuan Basin, southwestern China, for the aim of paleoclimate evaluation.

\section{Geological Setting and Sampling}

The Sichuan Basin is located in the western South China Block, where the Cretaceous strata are widely distributed [2]. The depositional age of studied strata ranges from Berriasian to Maastrichtian. Sediments are mostly fluvial to lacustrine origin, however, a broad distribution of aeolian dune sandstones was identified from the Cenomanian to Turonian interval [2]. 50 mudstone samples were collected from the five Cretaceous formations in the Sichuan Basin, covering the Berriasian to Maastrichtian stages. We exclusively sampled fine-grained massive mudstones in order to exclude compositional changes due to the grain-size effect.

\section{Analytical Methods}

Samples were pulverized using agate motor mill and fused beads were prepared for XRF analysis (ZSX Primus 2; Rigaku, Tokyo, Japan). The whole-rock major element composition acquired by XRF was used to calculate the W index [3] in order to evaluate the hinterland paleoweathering condition. Clay-mineral composition and illite crystallinity were obtained by XRD (SmartLab XRD, Rigaku, Tokyo, Japan). Oriented glass slides of clay minerals finer than $2 \mu \mathrm{m}$ fraction were prepared for the XRD measurement.

\section{Result and Discussion}

Geochemical weathering indices (e.g., W value; [3]) demonstrate a significant increase in hinterland paleoweathering from Berriasian $(\mathrm{W}=70)$ to Cenomanian - Turonian ( $\mathrm{W}=95$ ), and then slightly decrease towards the Maastrichtian $(\mathrm{W}=80)$. This fluctuation pattern of the weathering indices is concordant with the Cretaceous paleotemperature reconstruction curve [4]. Therefore, the present result suggests that the hinterland paleoweathering rate in the Sichuan Basin was governed by global temperature changes. The weathering index reached the maximum value of 95 in Cenomanian-Turonian interval. Furthermore, sediments of Cenomanian-Turonian horizons contained abundant kaolinite mineral, which is a product of hydrolysis decomposition of rock-forming minerals. Both lines of evidence suggest that the Sichuan Basin was under the tropical and pluvious climate during the Cenomanian-Turonian. Note that 
previous study elucidated an arid climate from amalgamated sandstone facies [2], while the present pluvious climate interpretation is derived from the analysis of intervening piled mudstone facies. When these lines of geological evidence are integrated together, it is reasonable to suggest the development of an alternating pluvious and arid paleoclimate during the Cenomanian-Turonian. The nature and trigger of this extremely oscillating pluvious/arid climate cannot be deduced solely from the present study. However, the timing of this renewed climate system matches with the Cretaceous greenhouse optimum (Cenomanian-Turonian). The development of monsoon-like pluvious/arid paleoclimate in the Sichuan Basin is possibly related to the mid-Cretaceous re-configuration in the global climate system.

\section{Conclusion}

In this study, the hinterland paleoweathering conditions in Sichuan Basin through the whole Cretaceous were reconstructed. We found that the fluctuation in hinterland paleoweathering intensity is highly positively correlated with the estimated global temperature trend. Therefore, the paleoweathering rate might be controlled by the global temperature. Furthermore, the present result suggests that mudstone facies intercalated in the aeolian sandstone facies record high rates of hinterland weathering intensity. The alternating mudstone and sandstone facies imply the oscillating pluvious/arid paleoclimate during the Cenomanian-Turonian greenhouse optimum.

\section{Acknowledgements}

This work was supported by JSPS (18K03787; T. Ohta), Strategic Priority Research Program of Chinese Academy of Sciences (XDB26000000) and NSFC (41572006, 41688103, 41972007). Thanks go to Prof. Y. Ogasawara of Waseda University and Mr. S. Yasutake for their help. This is a contribution to UNESCO/IUGS/IGCP 679.

\section{Conflicts of Interest}

The authors declare no conflicts of interest regarding the publication of this paper.

\section{References}

[1] Hasegawa, H., Tada, R., Jiang, X., Suganuma, Y., Imsamut, S., Charusiri, P., Ichinnorov, N. and Khand, Y. (2012) Drastic Shrinking of the Hadley Circulation during the Mid-Cretaceous Supergreenhouse. Climate of the Past, 8, 1323-1337. https://doi.org/10.5194/cp-8-1323-2012

[2] Li, Y., Li, C., He, D., Chen, L., Mei, Q. and Zhang, L. (2016) Cretaceous Sedimentary Basins in Sichuan, SW China: Restoration of Tectonic and Depositional Environments. Cretaceous Research, 57, 50-65. https://doi.org/10.1016/j.cretres.2015.07.013

[3] Ohta, T. and Arai, H. (2007) Statistical Empirical Index of Chemical Weathering in 
Igneous Rocks: A New Tool for Evaluating the Degree of Weathering. Chemical Geology, 240, 280-297. https://doi.org/10.1016/j.chemgeo.2007.02.017

[4] O’Brien, C.L., Robinson, S.A., Pancost, R.D., Sinninghe Damsté, J.S., Schouten, S., Lunt, D.J., Alsenz, H., Bornemann, A., Bottini, C., Brassell, S.C., Farnsworth, A., Forster, A., Huber, B.T., Inglis, G.N., Jenkyns, H.C., Linnert, C., Littler, K., Markwick, P., McAnena, A., Mutterlose, J., Naafs, B.D.A., Püttmann, W., Sluijs, A., van Helmond, N.A.G.M., Vellekoop, J., Wagner, T. and Wrobel, N.E. (2017) Cretaceous Sea-Surface Temperature Evolution: Constraints from TEX86 and Planktonic Foraminiferal Oxygen Isotopes. Earth-Science Reviews, 172, 224-247.

https://doi.org/10.1016/j.earscirev.2017.07.012 